\title{
Concentration-effect relationship after intravenous hydromorphone administration: Use of an effect compartment model and system analysis to minimize hysteresis of effects
}

D Westerling MD PhD, P Höglund MD PhD

\begin{abstract}
D Westerling, P Höglund.
Concentration-effect relationship after intravenous hydromorphone administration: Use of an effect compartment model and system analysis to minimize hysteresis of effects. Pain Res Manage 1997;2(3):167-172.
\end{abstract}

OBJECTIVE: To investigate the concentration-effect relationship of hydromorphone by using two different methods to minimize the hysteresis between concentration and effects.

DESIGN: Open study.

SUBJECTS: Twelve healthy volunteers.

MEASUREMENTS: The analgesic effect of hydromorphone, evaluated as pressure pain thresholds (PPTs), and nonanalgesic effects, miosis and reduction of saliva production, were related to the concentration of the opioid, analyzed by high performance liquid chromatography. Hysteresis between the concentration and the measured effects of hydromorphone was minimized by a link model and system analysis.

RESULTS: Parameter estimation was successful using both methods of hysteresis minimization. According to the link model, the mean concentration of hydromorphone at steady state $\left(\mathrm{C}_{\mathrm{ss} 50}\right)$ producing $50 \%$ of the $\mathrm{E}_{\max }$ for reduction of saliva production was $6.7 \pm 3.0 \mathrm{nmol} / \mathrm{L}$ and the mean $\mathrm{E}_{\max }$, given as the fraction of baseline salivation, was $-1.1 \pm 0.2$. Mean $\mathrm{C}_{\mathrm{ss} 50}$ for reduction of pupil size was $15 \pm 20 \mathrm{nmol} / \mathrm{L}$, and mean $\mathrm{E}_{\max }$ was $-0.8 \pm 0.2$. For analge- sia, mean $\mathrm{C}_{\mathrm{ss} 50}$ was $68 \pm 42 \mathrm{nmol} / \mathrm{L}$ and mean $\mathrm{E}_{\max }$ was $1.8 \pm 2.2$. Similar results were obtained by using system analysis.

CONCLUSION: Hydromorphone demonstrated a high intrinsic activity, producing miosis and dryness of the mouth. The analgesic effect of hydromorphone at the dose used in this laboratory setting was transient but significant. The link model and system analysis were equally efficient at evaluating the relation between concentration, and analgesic and nonanalgesic effects of hydromorphone, and gave similar results. Both methods may be useful in the study of pharmacodynamics of opioids.

Key Words: Effect modeling, Intravenous hydromorphone, Pharmacodynamics

\section{Relation effet-concentration après l'administration d'hydromorphone par voie intraveineuse : utilisation d'un modèle compartimental de l'effet et d'une analyse de système pour minimiser l'hystérésis des effets}

OBJECTIF : Investiguer la relation effet-concentration de l'hydromorphone en utilisant deux modèles différents pour minimiser l'hystérésis entre la concentration et les effets.

MODÈLE : Étude ouverte.

voir page suivante 
SUJETS : Douze volontaires sains.

MESURES : L'effet analgésique de l'hydromorphone évalué comme seuils de la douleur à la pression, et les effets non-analgésiques, le myosis et la réduction de la production de la salive ont été reliés à la concentration de l'opioïde et analysés par chromatographie liquide à haute performance. L'hystérésis entre la concentration et les effets mesurés de l'hydromorphone a été minimisée par un modèle en chaîne et une analyse de système.

RÉSULTATS : L'estimation des paramètres a été concluante avec l'utilisation des deux méthodes de minimisation de l'hystérésis. D'après le modèle en chaîne, la concentration moyenne d'hydromorphone à l'état d'équilibre $\left(\mathrm{C}_{\mathrm{ss} 50}\right)$ produisant $50 \%$ de l'effet maximal $\left(\mathrm{E}_{\max }\right)$ pour la diminution de la production de la salive était de $6,7 \pm 3,0 \mathrm{nmol} / \mathrm{L}$ et le $\mathrm{E}_{\max }$ moyen déterminé comme la fraction de la salivation à l'état basal était de $-1,1 \pm 0,2 . \mathrm{La} \mathrm{C}_{\mathrm{ss} 50}$ moyenne pour la réduction de la taille de la pupille était de $15 \pm 20 \mathrm{nmol} / \mathrm{L}$ et le $\mathrm{E}_{\max }$ moyen était de $-0,8 \pm 0,2$. Pour l'analgésie, la $\mathrm{C}_{\mathrm{ss} 50}$ moyenne était de $68 \pm 42 \mathrm{nmol} / \mathrm{L}$ et le $\mathrm{E}_{\max }$ moyen était de $1,8 \pm 2,2$. Des résultats similaires ont été obtenus en utilisant l'analyse de système.

CONCLUSION : L'hydromorphone a démontré une forte activité intrinsèque, produisant un myosis et une sécheresse de la bouche. L'effet analgésique de l'hydromorphone à la dose utilisée dans cet essai était transitoire mais significatif. Le modèle en chaîne et l' analyse de système ont démontré une efficacité comparable pour évaluer la relation entre la concentration, et les effets analgésiques et non-analgésiques de l'hydromorphone, et ont donné des résultats similaires. Les deux méthodes pourraient être utiles dans l'étude de la pharmacocinétique des opioïdes.
$\mathrm{T}$ he analgesic and nonanalgesic effects of opioids are attributed to interactions at opioid receptors within the central nervous system, but peripheral opioid receptors may also be responsible for analgesic and nonanalgesic effects encountered during opioid therapy (1). Concentrations of opioids at the corresponding receptor sites cannot be measured directly, whereas plasma concentrations of opioids may be available.

The correlation between analgesia and plasma concentrations of morphine $(2,3)$ is poor. Interpretation of the results is complicated by the presence of active metabolites of morphine and hysteresis of the measured and/or evaluated effects in relation to observed plasma concentrations of the given drug. For other more potent opioids such as fentanyl and alfentanil, a closer correlation between analgesic effect and plasma drug concentrations has been proposed $(4,5)$. However, plasma concentrations of these synthetic opioids associated with analgesia exhibit wide interindividual variation $(5,6)$.

Increased knowledge of concentration-effect relationships for opioids may improve the quality of analgesic therapy $(7,8)$. This may be achieved by facilitating the choice of adequate doses and dosing intervals during patient-controlled analgesia with or without background continuous infusions. Also, for perioperative opioid infusions the relationship between opioid effects and concentration is of crucial importance to provide safe antinociception during anesthesia without overdosing, which prolongs recovery (6). The analgesic effect of opioids is difficult to quantify and compare between individual subjects, whereas in healthy subjects, experimental pain lacks the emotional components of clinical pain. Unlike analgesia, side effects of opioids, such as miosis and decrease of saliva production, can be measured accurately (9-12). The $\mathrm{E}_{\max }$ model $(13,14)$ was applied after administration of morphine to healthy subjects $(9,11)$, where these nonanalgesic effects were shown to be related to estimated effect compartment concentrations.

Compartment analysis defines a hypothetical effect compartment in which the effect site concentration can be estimated $(13,14)$. System analysis, on the other hand, is based on hysteresis minimization using a conductance function without assuming a specific compartmental structure for the pharmacokinetic-pharmacodynamic relationship (15). Other models for study of the link between concentration and effect are also possible, including the possibility of disregarding the hysteresis of the observed effects and, thus, using the plasma concentration directly in the concentration-effect analysis. This procedure may be useful for lipophilic, potent opioids such as sufentanil or alfentanil, where hysteresis of the concentration and analgesic effect may be small $(4,5)$ but may pose problems in concentration-effect studies of more hydrophilic, less potent opioids such as hydromorphone, used by different routes of administration as an alternative to morphine in the treatment of severe malignant pain $(16,17)$ and postoperative pain $(18,19)$.

Previously reported analgesic and nonanalgesic effects after intravenous administration of hydromorphone to 12 healthy volunteers appeared to be related to plasma concentrations of the drug (12). The effect variables comprised analgesia, studied as pressure pain thresholds (PPTs), and nonanalgesic effects of hydromorphone, measured as miosis and saliva production. To better characterize the concentration-effect relationship of hydromorphone, individual data from the previous study were investigated further. The observed hysteresis between plasma concentrations of hydromorphone over time and concomitant measurements of effects was minimized by using compartment and system analysis.

\section{SUBJECTS AND METHODS}

Twelve healthy volunteers, seven men and five women ages 23 to 40 years and weighing $70.5 \pm 8.4 \mathrm{~kg}$ (mean $\pm \mathrm{SD}$ ), participated in the study after giving their written, informed consent. Subjects were all well known to the investigators, had no history of drug or alcohol abuse and were found to be healthy in the prestudy examination, which included physical examination, and blood and urine chemistry.

The study was approved by the ethics committee of the University of Lund, Lund, Sweden and by the Swedish Medical Products Agency, Uppsala, Sweden.

Details of the subjects, measurements, procedure and pharmacokinetics have been given previously (12).

\section{Procedure and measurements}

After an overnight fast, the subjects received an intravenous infusion of $2 \mathrm{mg}$ hydromorphone hydrochloride $(6.22 \mu \mathrm{mol}$ hydromorphone hydrochloride) over 20 mins in an antecubital vein. Venous blood samples were drawn from a short indwelling catheter in the other arm before the infusion and at 5, 10, 20, 25, 30, 45, 60, 80 and 100 mins, and at 2.17, 3.17, 4.17, 5.17, 6.17, 8.17, 11.17, 14.17, $24.17,30.17,48.17$ and $72.17 \mathrm{~h}$ after the start of the infusion. Plasma samples were prepared and assayed for hydromorphone by high performance liquid chromatography (12). 
Oxygen saturation was registered by pulse oxymetry (Oxycap 4700, Ohmeda, Kentucky) when blood samples were drawn. Unstimulated salivation was measured by the method described by Heintze et al (20). Two measurements were made before administration of the drug and at regular intervals during the procedure. The subjects were asked to spit into a preweighed plastic cup for 5 mins. The cup was then weighed. The mean of the two predrug measurements was considered as baseline saliva production.

The right eye was photographed under standardized conditions, before and at regular intervals after administration of hydromorphone. The diameters of the pupil and iris were measured on the negative film and the pupil:iris diameter ratio was calculated (10). The ratio was chosen to ascertain that the measurements were made in the same frontal plane.

PPTs were measured using an algometer (Somedic AB, Sollentuna, Sweden). The measurements were made using the stimulation unit as a pair of forceps. A circular probe with a diameter of $6 \mathrm{~mm}$ (area $28 \mathrm{~mm}^{2}$ ) was applied to the dorsum of the second phalanx of the third finger of both hands and to the third toe of both feet. The pressure application rate was $1.1 \mathrm{~N} / \mathrm{s}$ (21). When the subjects perceived the pressure exerted by the forceps change into a painful stimulus they activated a push button. The pressure was given in kilopascals on a digital display kept out of sight of the volunteers. Three consecutive measurements separated by 10 to $15 \mathrm{~s}$ were made. The median value of the three measurements at each location was used. All effects are shown as fractions of the individual baseline values measured before drug administration. The results are generally presented as individual data or mean \pm SD.

\section{Data analysis: Effect compartment model}

The pharmacokinetic-pharmacodynamic model used in this scheme was composed of a central and peripheral compartment. It was assumed that the effect compartment was driven by the central compartment with the rate $\mathrm{k}_{1 \mathrm{e}}$. The exit rate from the effect compartment was $\mathrm{k}_{\mathrm{e} 0}$. The rate of infusion was $\mathrm{k}_{0}$ and the intercompartmental transfer rates were $\mathrm{k}_{12}$ and $\mathrm{k}_{21}$.

The $\mathrm{E}_{\max }$ model $(13,14)$ was used to estimate the maximal effect $\left(\mathrm{E}_{\max }\right)$ and the concentration of hydromorphone at steady state in a hypothetical effect compartment at $50 \%$ of the maximal effect $\left(\mathrm{C}_{\mathrm{Ss} 50}\right)$ :

$$
E=E_{0}+\frac{E_{\max } \cdot C_{e}}{C_{s s} 50+C_{e}}
$$

where $\mathrm{C}_{\mathrm{e}}$ denotes the concentration producing a corresponding effect $\mathrm{E}$, and $\mathrm{E}_{0}$ is the baseline effect before drug administration.

The amounts of drug in the central and effect compartments were calculated using equations given earlier (9) and were defined as the product of the input and output disposition functions (22-25). $\mathrm{k}_{\mathrm{e} 0}$ was also obtained from these equations.

\section{System analysis}

An alternative method using a noncompartmental, system analysis pharmacodynamic approach according to Veng-Pedersen et al (26) and Modi and Veng-Pedersen (15) was also performed. Because the hypothetical effect site concentration could not be measured, a conductance function was employed (27). The hysteresis between concentration and effect of the given drug was minimized through an iterative search for a biophase level that optimally agreed with the measured effect (26). The biophase concentration, or the normalized effect site concentration, then equals the plasma concentration of hydromorphone at steady state.

$\mathrm{C}_{\mathrm{Ss} 50}$ and $\mathrm{E}_{\max }$ were obtained using the $\mathrm{E}_{\max }$ model according to Modi and Veng-Pedersen (15) and Mandema et al (27):

$$
E=E_{0}+\frac{E_{\max } \cdot C_{b}}{C_{s 5} 50+C_{b}}
$$

where $\mathrm{C}_{\mathrm{b}}$ is the biophase concentration producing the effect $\mathrm{E}$.

The pharmacodynamic variables were calculated for every individual with the corresponding values of PPT, reduction of saliva production and pupil size as effect variables.

\section{RESULTS}

The intravenous infusion of hydromorphone was associated with sedation, drowsiness and heaviness in all subjects. Nausea and pruritus were reported by five and eight subjects, respectively. The effects were well tolerated and required no medical treatment. Oxygen saturation remained normal throughout the trial. Following intravenous infusion of hydromorphone, a significant increase of mean values of PPT was registered in the third fingers and third toes lasting for up to $2 \mathrm{~h}$ after the start of the infusion.

The mean pupil size and mean saliva production were significantly reduced for up to $6 \mathrm{~h}$ after drug infusion. Details of the described analgesic and nonanalgesic effects have been given previously (12).

\section{Pharmacodynamics}

The parameter estimation was successful in all subjects. All $\mathrm{E}_{\max }$ values are given as fraction of individual baseline values. Negative $\mathrm{E}_{\max }$ values were obtained for reduction of saliva production and pupil size.

In the effect compartment model, mean $\mathrm{E}_{\max }$ for saliva production was $-1.1 \pm 0.2$, mean $\mathrm{C}_{\mathrm{ss} 50}$ was $6.7 \pm 3.0 \mathrm{nmol} / \mathrm{L}$ and mean $\mathrm{k}_{\mathrm{e} 0}$ was $2.8 \pm 1.8 / \mathrm{h}$. According to system analysis, the mean $\mathrm{E}_{\max }$ for saliva production was $-1.0 \pm 0.2$ and the mean $\mathrm{C}_{\mathrm{ss} 50}$ was $5.6 \pm 3.1 \mathrm{nmol} / \mathrm{L}$. Individual pharmacodynamic parameters are given in Tables 1 and 2 .

Mean $\mathrm{E}_{\max }$ for reduction of pupil size was $-0.8 \pm 0.2$, mean $\mathrm{C}_{\mathrm{ss} 50}$ was $15 \pm 20 \mathrm{nmol} / \mathrm{L}$ and mean $\mathrm{k}_{\mathrm{e} 0}$ was $2.4 \pm 3.6 / \mathrm{h}$ in the effect compartment model. Using the system analysis, mean $\mathrm{E}_{\max }$ was $-0.8 \pm 0.2$ and mean $\mathrm{C}_{\mathrm{Ss} 50}$ was $18 \pm 20 \mathrm{nmol} / \mathrm{L}$.

A mean $\mathrm{E}_{\max }$ for analgesia of $1.8 \pm 2.2$, a mean $\mathrm{C}_{\mathrm{Ss} 50}$ of $68 \pm 42$ $\mathrm{nmol} / \mathrm{L}$ and a mean $\mathrm{k}_{\mathrm{e} 0}$ of $4 \pm 4 / \mathrm{h}$ were obtained in the effect compartment model. Using system analysis, the mean $\mathrm{E}_{\max }$ for analgesia was $1.3 \pm 2.2$ and mean $\mathrm{C}_{\mathrm{ss} 50}$ was $31 \pm 45 \mathrm{nmol} / \mathrm{L}$.

Figure 1 shows the reduction of saliva production and the analgesic effect given as fraction of baseline values, and the concomitant concentrations of hydromorphone obtained in a representative patient in plasma without hysteresis minimization, in a hypothetical effect site according to the link model and in the biophase by using hysteresis minimization according to system analysis. The reduction of pupil size demonstrated similar curves as those obtained for the reduction of saliva production but are not included.

The effect compartment model and the system analysis produced similar results. All parameters were estimated simultaneously in the effect compartment model, whereas system analysis involved a two-step procedure. 


\begin{tabular}{|lccc|}
\hline $\begin{array}{l}\text { TABLE 1 } \\
\text { Hydromorphone infusions: pharmacodynamic parameter } \\
\text { estimates for reduction of saliva production using a link } \\
\text { model }\end{array}$ \\
\hline Subject & $\mathbf{E}_{\mathbf{m a x}}$ & $\mathbf{C}_{\mathbf{s s} 50}$ (nmol/L) & $\mathbf{k}_{\mathbf{e} \mathbf{0}}(\mathbf{h})$ \\
\hline 1 & -1.0 & 6.2 & 2.5 \\
2 & -1.0 & 3.5 & 1.1 \\
3 & -1.5 & 9.5 & 1.9 \\
4 & -1.4 & 11.0 & 2.1 \\
5 & -1.2 & 7.7 & 1.8 \\
6 & -0.8 & 1.3 & 0.7 \\
7 & -1.0 & 4.4 & 2.2 \\
8 & -1.0 & 7.2 & 2.9 \\
9 & -1.0 & 2.8 & 5.1 \\
10 & -1.1 & 8.3 & 1.4 \\
11 & -1.2 & 8.1 & 5.8 \\
12 & -1.1 & 9.8 & 6.0 \\
Mean \pm & $-1.1 \pm 0.2$ & $6.7 \pm 3.0$ & $2.8 \pm 1.8$ \\
\hline$C_{s s 50}$ Mean concentration of hydromorphone at a steady state; & \\
$E_{\text {max }}$ Maximal effect; & $k_{\mathrm{e} 0}$ Exit rate from the effect compartment \\
& & & \\
\hline
\end{tabular}

\section{DISCUSSION}

Nonanalgesic effects of opioids are encountered frequently in pain therapy and may significantly affect patient compliance. Dryness of the mouth is a side effect of morphine $(28,29)$ that was reported to be highly associated with morphine therapy in chronic pain patients (30). Following different routes of morphine administration to healthy volunteers, a significant reduction of saliva production was registered (9-11). Also, hydromorphone, given as an intravenous infusion over 20 mins, significantly reduced saliva production (12), which in the present analysis was shown to be well related to the estimated concentration of the opioid in a hypothetical effect compartment. The mean $\mathrm{C}_{\mathrm{ss} 50}$ value for morphine for unstimulated saliva production in a similar group of healthy volunteers was $50.3 \mathrm{nmol} / \mathrm{L}(31)$, whereas the corresponding mean $\mathrm{C}_{\mathrm{ss} 50}$ value for hydromorphone was $6.7 \mathrm{nmol} / \mathrm{L}$. This indicates a higher potency (approximately 7.5 times) of hydromorphone compared with morphine for reduction of saliva production, corresponding well with the reported higher potency of hydromorphone compared with morphine for analgesia (1:7.7) (32). In our effect modelling of morphine the contribution of metabolites to the effect was included (31), whereas in the present analysis of hydromorphone the possible effects of metabolites were not considered, although a possible contribution of metabolites to side effects of hydromorphone, like myoclonus, has been suggested (33) but not proven.

Miosis may be a useful clinical sign in cases of opioid overdose and has been reported to occur in minutes following intravenous administration of morphine and alfentanil (34). The reduction of pupil size following opioid administration may offer possibilities to measure an opioid receptor effect noninvasively and accurately over an administration interval.

In our study, miosis was also related to the concentrations of hy-
TABLE 2

Hydromorphone infusions: pharmacodynamic parameter estimates for reduction of saliva production using system analysis

\begin{tabular}{lcc}
\hline Subject & $\mathbf{E}_{\mathbf{m a x}}$ & $\mathbf{C}_{\mathbf{s s} 50}(\mathbf{n m o l} / \mathbf{L})$ \\
\hline 1 & -0.9 & 4.7 \\
2 & -0.8 & 0.6 \\
3 & -1.4 & 8.8 \\
4 & -1.3 & 9.8 \\
5 & -1.1 & 6.4 \\
6 & -0.8 & 0.4 \\
7 & -0.9 & 3.7 \\
8 & -1.0 & 6.2 \\
9 & -1.0 & 3.3 \\
10 & -1.1 & 8.7 \\
11 & -1.2 & 7.4 \\
12 & -1.0 & 7.6 \\
Mean \pm SD & $-1.0 \pm 0.2$ & $5.6 \pm 3.1$ \\
\hline$C_{\text {ss50 }}$ Mean concentration & of hydromorphone at a steady state; \\
$E_{\text {max }}$ Maximal effect & & \\
\hline
\end{tabular}

dromorphone. The estimation of parameters was less successful for miosis than for reduction of saliva production, possibly due to the absence of early measurements of pupil size during the infusion. Such registrations were not possible for practical reasons. Maximal reduction of the pupil size was already evident on the first measurement, performed 6 mins after the end of the infusion. Compared with a corresponding value of $\mathrm{C}_{\mathrm{ss} 50}$ for morphine and miosis ( $27 \mathrm{nmol} / \mathrm{L}$ ) obtained in a similar group of volunteers (31), hydromorphone was approximately two times more potent than morphine for producing miosis. The values of $\mathrm{E}_{\max }$ for reduction of saliva production and pupil size produced by hydromorphone in the present study ( -1.1 and -0.8 , respectively) and the corresponding values of $E_{\max }$ reported for morphine in a previous study (11) were comparable, implying a similar, high intrinsic activity of the two opioids regarding dryness of the mouth and miosis.

The studied nonanalgesic effects, reduction of pupil size and saliva production, may be of minor clinical importance. However, these opioid effects were consistent, easy to measure and outlasted the analgesic action of hydromorphone by many hours. The analgesic action of hydromorphone, measured in this study as an increase of PPT, produced large standard deviations of the pharmacodynamic variables in both models. This may have been due to several reasons, like the limited number of observations of PPT possible during and immediately after infusion of the drug where the plasma concentrations were higher than those that occurred later in the treatment. The absent analgesic effect at lower plasma concentrations is in accordance with the findings of Reidenberg et al (35), where patients suffering from chronic pain seldom reported sufficient pain relief at plasma concentrations of hydromorphone lower than $4 \mathrm{ng} / \mathrm{mL}$. However, it should be emphasized that experimental pain and analgesia are not equvalent to pain and pain relief in pa- 

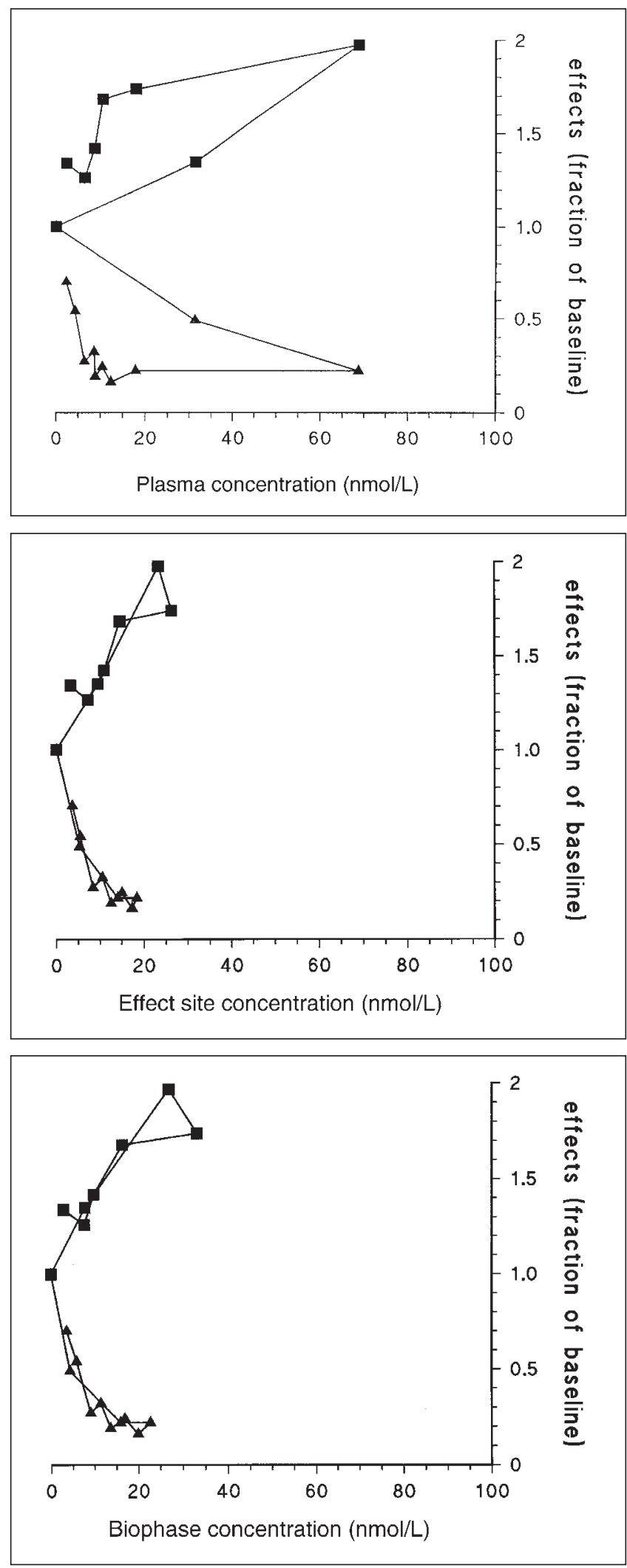

Figure 1) Hysteresis plots, originating from a concentration of $0 \mathrm{nmol} / \mathrm{L}$ and effects (fraction of baseline) 1.0. Saliva production (fraction of baseline value $\mathbf{\Delta}$ ) and increase of pressure pain thresholds (fraction of baseline value in a representative subject versus plasma concentrations of hydromorphone (top); versus effect site concentrations of hydromorphone after hysteresis minimization using a link model (middle); and versus concentrations of hydromorphone in the biophase after hysteresis minimization using system analysis (bottom) tients in a clinical setting (36). The open design of our study includes expectations of analgesia in both investigators and healthy volunteers. However, the volunteers were not shown the digital display of the algometer and were thus unaware of the actual measured PPT. PPTs have been used to detect analgesic effects of other opioids, such as morphine, codeine and tramadol (37).

To detect an individual relationship between concentrations of opioids and analgesia, the assumed analgesic concentrations may have to be maintained for longer than our $20 \mathrm{~min}$ infusion. Prolonged infusion periods were used in healthy subjects given target designed opioid (morphine, fentanyl and alfentanil) infusions, where a linear relationship between pain relief and the obtained steady state plasma concentrations of the respective opioids was reported (38). In cancer patients, pain relief and sedation were related to effect compartment concentrations of methadone following intravenous infusion of the drug for several hours (7).

In the present study, all effect variables are given as a fraction of values obtained immediately before drug administration. Ratios exceeding 1.0 are thus possible. Erroneously high baseline PPTs may reduce the later possible increase of PPT during drug treatment. Also, the validity and reproducibility of the analgesic test we used may have contributed to the less evident relation between analgesia and concentration of hydromorphone. However, Dahl et al (39) reported a low variability in three consecutive tests of PPT in healthy volunteers and in patients operated for inguinal hernia.

A further factor influencing our analysis of the relationship between concentration and analgesia may reflect the reported and well known large interindividual variability in the analgesic effect of a given dose of opioids (32), and hydromorphone is possibly no exception to other studied opioids $(32,40)$. The given dose of hydromorphone, $2 \mathrm{mg}$, may have been too low for some of our volunteers to achieve significant analgesic effects, although significant nonanalgesic effects were present in all subjects.

In conclusion, the reduction of saliva production was well related to concentrations of the drug estimated in a hypothetical effect compartment. Concentrations in a biophase estimate of steady state plasma concentrations were also well related to the reduced saliva production. Significant analgesic effect and miosis were observed and were related to drug concentrations. System analysis and the link model were equally efficient at evaluating the relation between concentration and effects of hydromorphone, and gave similar results. Both methods may be useful in the study of the pharmacodynamics of opioids. The effect compartment model allows simultaneous estimation of parameters, which may be an advantage, whereas system analysis requires a two-step procedure, which may increase possible errors of the estimates. On the other hand, in system analysis the measurement of drug concentrations is not required, because the drug infusion rate can also be used in the calculations $(15,41)$. This may be an advantage in clinical studies of opioids in patients, in whom sampling of blood and subsequent analysis of opioids may pose problems.

ACKNOWLEDGEMENT: This study was supported by grants from G, A och E Nilssons Stiftelse för bekämpning av cancersjukdomar, Stiftelsen Claes Groschinskys Minnesfond, Stockholm and the Medical Faculty of the University of Lund, Lund, Sweden. 


\section{REFERENCES}

1. Stein C. Peripheral mechanisms of opioid analgesia. Anesth Analg 1993;76:182-91.

2. Dahlström B, Tamsen A, Paalzow L, Hartvig P. Patient-controlled analgesic therapy, part IV: Pharmacokinetics and plasma concentrations of morphine. Clin Pharmacokinet 1982;7:266-79.

3. Glare PA, Walsh TD. Clinical pharmacokinetics of morphine. Ther Drug Monit 1991;13:1-23.

4. Gourlay GK, Kowalski SR, Plummer JL, Cousins MJ, Armstrong PJ. Fentanyl blood concentration-analgesic response relationship in the treatment of postoperative pain. Anesth Analg 1988;67:329-37.

5. Ausems ME, Hug CC, Stanski DR, Burm AGL. Plasma concentrations of alfentanil required to supplement nitrous oxide for general surgery. Anesthesiology 1986;65:362-73.

6. Lemmens HJM. Pharmacokinetic-pharmacodynamic relationships for opioids in balanced anaesthesia. Clin Pharmacokinet 1995;29:231-42.

7. Inturrisi CE, Portenoy RK, Max MB, Colburn WA, Foley KM. Pharmacokinetic-pharmacodynamic relationships of methadone infusions in patients with cancer pain. Clin Pharmacol Ther 1990;47:565-77.

8. Inturrisi CE, Colburn WA. Application of pharmacokinetic-pharmacodynamic modeling to analgesia. In: Foley KM, Inturrisi CE, eds. Advances in Pain Research and Therapy, vol 8. New York: Raven Press, 1986:441-52.

9. Westerling D, Frigren L, Höglund P. Morphine pharmacokinetics and effects on salivation and continuous reaction times in healthy volunteers. Ther Drug Monit 1993;15:364-74.

10. Westerling D, Höglund P, Lundin S, Svedman P. Transdermal administration of morphine to healthy subjects. Br J Clin Pharmacol 1994;37:571-6.

11. Westerling D, Persson C, Höglund P. Plasma concentrations of morphine, morphine-3-glucuronide and morphine-6-glucuronide after iv and oral administration to healthy volunteers and their relation to some non-analgesic actions. Ther Drug Monitor 1995; 17:287-301.

12. Westerling D, Björk H, Svedman P, Höglund P. Analgesic and nonanalgesic effects of intravenous hydromorphone - Relation to plasma concentrations in healthy volunteers. Pain Res Manage 1996;1:86-92.

13. Holford NHG, Sheiner LB. Understanding the dose-effect relationship: Clinical application of pharmacokinetic-pharmacodynamic models. Clin Pharmacokinet 1981;6:429-53.

14. Holford NHG, Sheiner LB. Kinetics of pharmacological response. Pharmacol Ther 1982;16:143-66.

15. Modi NB, Veng-Pedersen P. Application of a variable direction hysteresis minimization approach in describing the central nervous system pharmacodynamic effects of alfentanil in rabbits. J Pharm Sci 1994;83:351-6.

16. Bruera E, Brenneis C, Michaud M, et al. Use of the subcutaneous route for the administration of narcotics in patients with cancer pain. Cancer 1988;62:407-11.

17. Moulin DE, Kreeft JH, Murray-Parsons N, Bouquillon AI. Comparison of continuous subcutaneous and intravenous infusions for management of cancer pain. Lancet 1991;337:465-8.

18. Searle NR, Roy M, Bergeron G, et al. Hydromorphone patient-controlled analgesia (PCA) after coronary artery bypass surgery. Can J Anaesth 1994;41:198-205.

19. Rapp SE, Egan KJ, Ross BK, Wild LM, Terman GW, Ching JM. A multidimensional comparison of morphine and hydromorphone patient-controlled analgesia. Anesth Analg 1996;82:1043-8.

20. Heintze U, Birkhed D, Björn H. Secretion rate and buffer effect of resting and stimulated whole saliva as a function of age and sex. Swed Dent J 1983;7:227-38.
21. Brennum J, Kjeldsen M, Jensen K, Jensen TS. Measurement of human pressure-pain thresholds on fingers and toes. Pain 1989;38:211-7.

22. Benet LZ, Turi JS. Use of general partial fraction theorem for obtaining inverse Laplace transforms in pharmacokinetic analysis. J Pharm Sci 1971;60:1593-4.

23. Benet LZ. General treatment of linear mammillary models with elimination from any compartment as used in pharmacokinetics. J Pharm Sci 1972;61:536-41.

24. Haborak GE, Benmaman JD, Warren JW. Mathemetical treatment of linear mammillary models using inverse Laplace transforms. J Pharm Sci 1979;68:932-3.

25. Benet LZ. Mathematical treatment of linear mammillary models using inverse Laplace transforms: A reply. J Pharm Sci 1979;68:933-4.

26. Veng-Pedersen P, Modi NB, Widness JA, Pereira LM, Schmidt RL, Georgieff MK. A system approach to pharmacodynamics. Plasma iron mobilization by endogenous erythropoietin in the sheep fetus; evidence of threshold response in spontaneous hypoxemia. J Pharm Sci 1993;82:804-7.

27. Mandema JW, Heijligers-Feijen CD, Tukker E, De Boer AG, Danhof M. Modeling of the effect site equilibration kinetics and pharmacodynamics of racemic baclofen and its enantiomers using quantitative EEG effect measures. J Pharmacol Exp Ther 1992;261:88-95.

28. Jaffe JH, Martin WR. Opioid analgesics and antagonists. In: Goodman Gilman A, Goodman LS, Rall TW, Murad F, eds. Goodman and Gilman's: The pharmacological Basis of Drug Treatment, 7th edn. New York: Macmillan Publishing Company, 1985:498.

29. Martindale W. Martindale the Extra Pharmacopeia, 29th edn. London: Pharmaceutical Press, 1989:1311.

30. White ID, Hoskin PJ, Hanks GW, Bliss JM. Morphine and dryness of the mouth. BMJ 1989;298:1222-3.

31. Westerling D. Studies on morphine and its main metabolites in man and rat. Doctoral thesis. Lund: Lund University, 1993:50.

32. Reisine T, Pasternak G. Opioid analgesics and antagonists. In: Hardman JG, Limbird LE, Molinoff PB, Ruddon RW, Goodman Gilman A, eds. Goodman and Gilman's the Pharmacological Basis of Drug Treatment, 9th edn. New York: McGraw-Hill, 1996:528-33.

33. Babul N, Darke AC. Putative role of hydromorphone metabolites in myoclonus. Pain 1992;51:260-1. (Lett)

34. Miller CD, Asbury AJ, Brown JH. Pupillary effects of alfentanil and morphine. Br J Anaesth 1990;65:415-7.

35. Reidenberg MM, Goodman H, Erle H, et al. Hydromorphone levels and pain control in patients with severe chronic pain. Clin Pharmacol Ther 1988;44:376-82.

36. Gracely RH. Experimental pain models. In: Max M, Portenoy R, Laska E, eds. Advances in Pain Research and Therapy. New York: Raven Press, 1991;18:33-47.

37. Poulsen L, Arendt-Nielsen L, Brosen K, Sindrup SH. The hypoalgesic effect of tramadol in relation to CYP2D6. Clin Pharmacol Ther 1996;60:636-44.

38. Hill HF, Chapman CR, Saeger LS, et al. Steady-state infusions of opioids in human II. Concentration-effect relationships and therapeutic margins. Pain 1990;43:69-79.

39. Dahl JP, Rosenberg J, Molke Jensen F, Kehlet H. Pressure pain thresholds in volunteers and herniorraphy patients. Acta Anaesthesiol Scand 1990;34:673-6.

40. Inturrisi CE, Colburn WA, Kaiko RF, Houde RW, Foley KM. Pharmacokinetics and pharmacodynamics of methadone in patients with chronic pain. Clin Pharmacol Ther 1987;41:392-401.

41. Veng-Pedersen P, Modi NB. A system approach to pharmacodynamics. Input-effect control system analysis of central nervous system effect of alfentanil. J Pharm Sci 1993;82:266-72. 


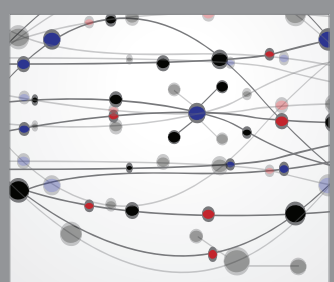

The Scientific World Journal
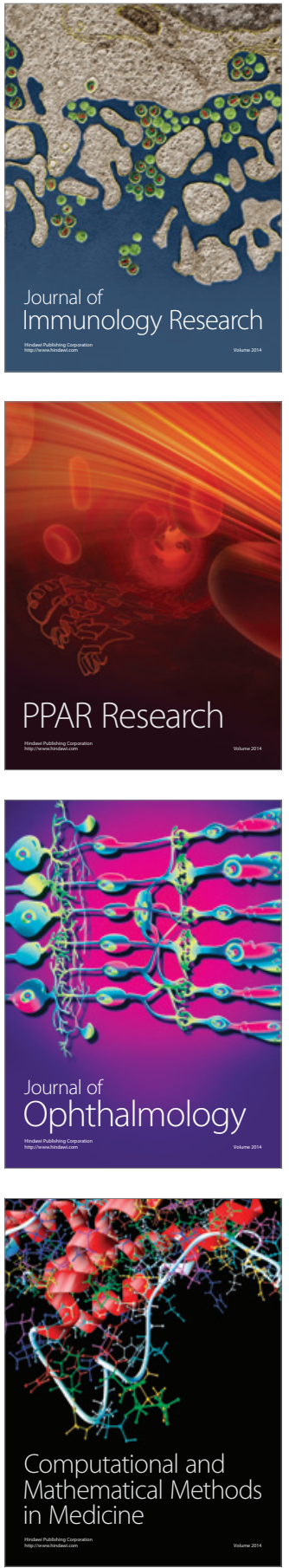

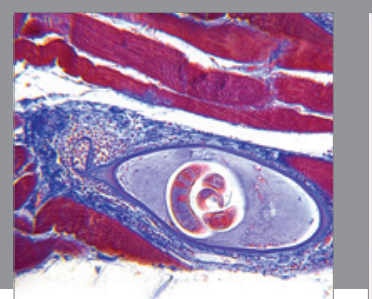

Gastroenterology Research and Practice

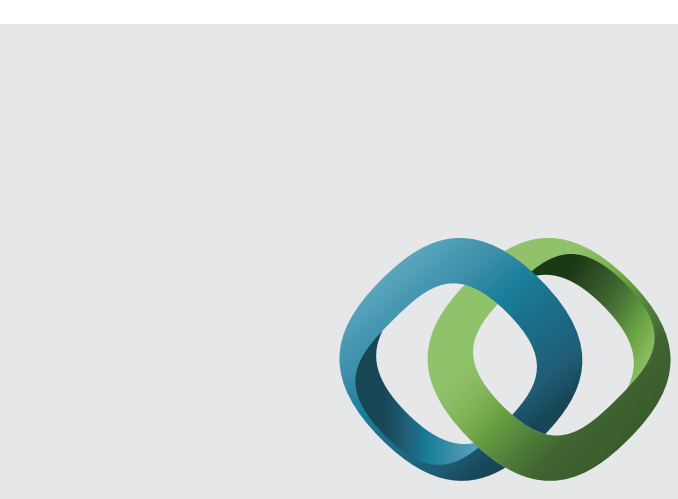

\section{Hindawi}

Submit your manuscripts at

http://www.hindawi.com
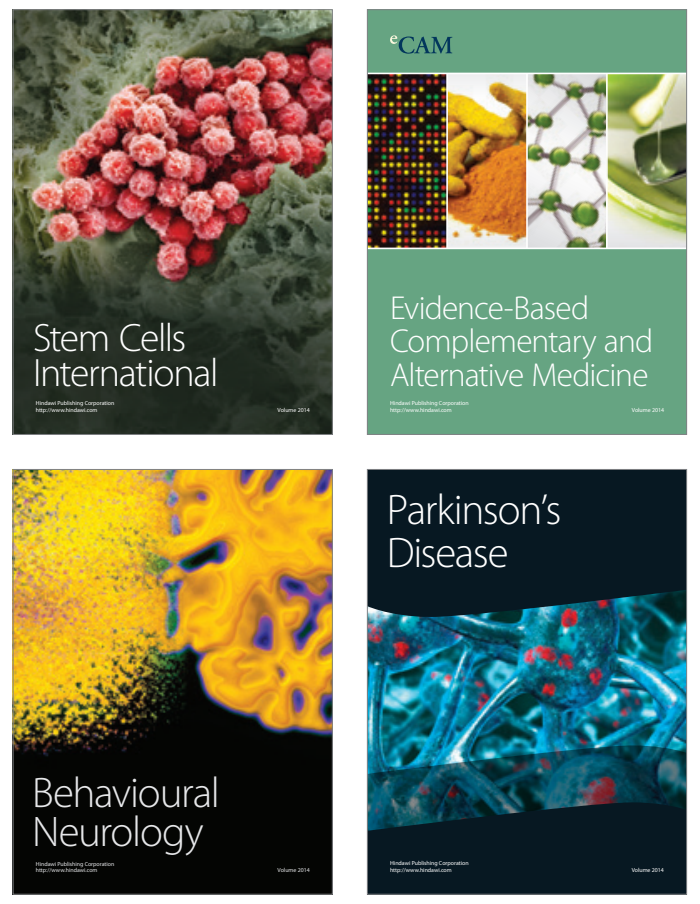
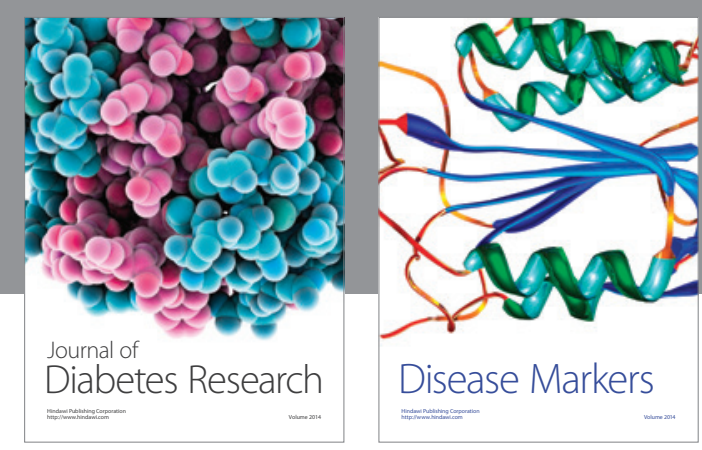

Disease Markers
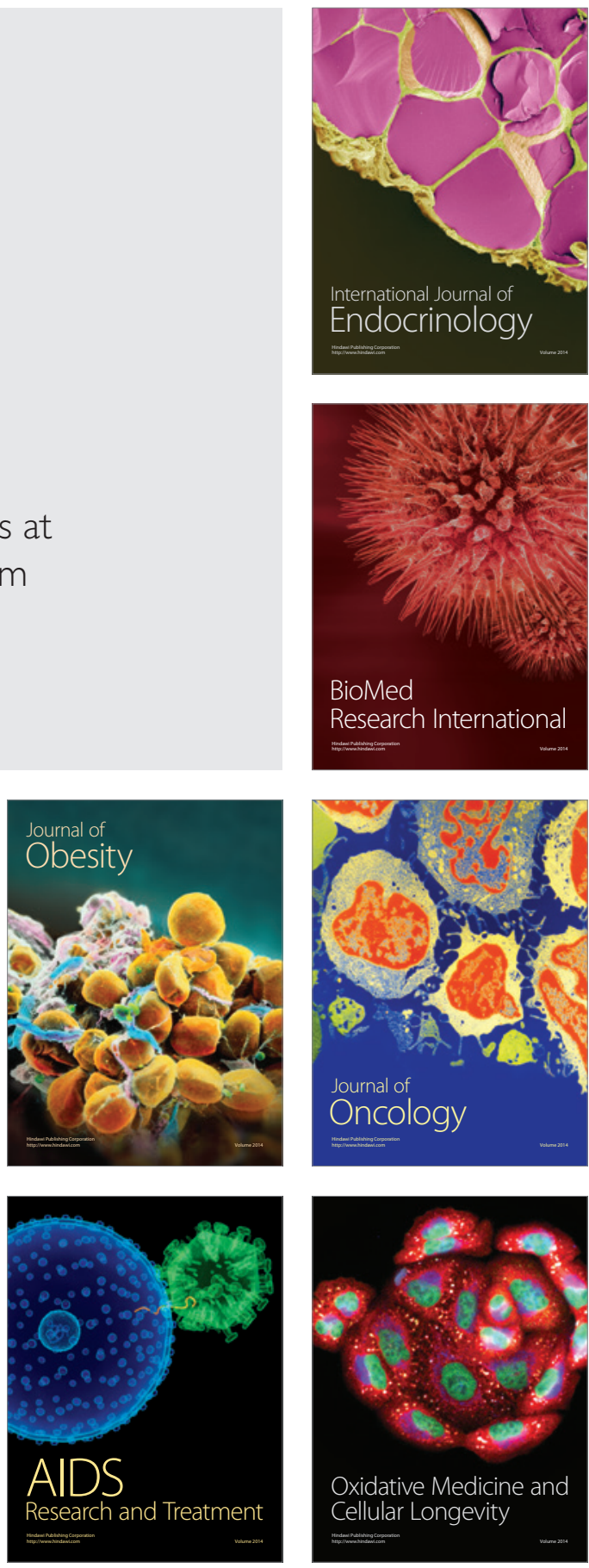